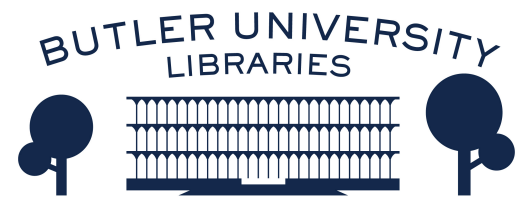

Journal of Hindu-Christian Studies

Volume 31 Celebrating Rāmānuja at 1000: The

Heritage and Promise of the Study of Rāmānuja

in a Christian-Hindu Comparative Theology

Article 22

2018

\title{
Why Rāmānuja? Some Reflections on Christian-Vaișṇava Comparative Theology
}

Gopal Gupta

University of Evansville

Follow this and additional works at: https://digitalcommons.butler.edu/jhcs

\section{Recommended Citation}

Gupta, Gopal (2018) "Why Rāmānuja? Some Reflections on Christian-Vaiṣnava Comparative Theology," Journal of Hindu-Christian Studies: Vol. 31, Article 22.

Available at: https://doi.org/10.7825/2164-6279.1699

The Journal of Hindu-Christian Studies is a publication of the Society for Hindu-Christian Studies. The digital version is made available by Digital Commons @ Butler University. For questions about the Journal or the Society, please contact cbauman@butler.edu. For more information about Digital Commons @ Butler University, please contact digitalscholarship@butler.edu. 


\title{
Why Rāmānuja? Some Reflections on Christian- Vaiṣnava Comparative Theology
}

\author{
Gopal Gupta \\ University of Evansville
}

\begin{abstract}
This paper examines the very idea of developing a Christian-Hindu comparative theology by focusing on Rāmānuja in particular. The paper begins by reflecting on some possible reasons--social, political, theological and philosophical-that Rāmānuja, instead of Madhva and other Vaișnavas, has held, and continues to hold, such a central place in Christian-Vaiṣnava comparative work. It then compares the Thomist doctrine of creation ex-nihilo with the theologies of Rāmānuja, Madhva and Jiva Goswami to illustrate that engaging with multiple Vaiṣnava voices can enrich and expand the Christian-Rāmānuja comparative discourse.

Śankkara and Rāmānuja have frequently emerged as the "go-to" thinkers for ChristianHindu comparative theologians. And in the narrower area of Christian-Vaiṣnava comparative study, Rāmānuja has been most popular, both historically and in recent years. Due to his insistence on difference between souls, the world and God, and his relentless monotheism, Madhva seems to be a natural comparand for the Christian-Vaiṣnava comparativist. This essay begins by reflecting
\end{abstract}

on some possible reasons that Rāmānuja, instead of Madhva and other Vaișnavas, has held, and continues to hold, such a central place in Christian-Vaișnava comparative work. This essay then compares the Thomist doctrine of creation ex-nihilo with the theologies of Rāmānuja, Madhva and Jīva Goswami to illustrate that engaging with multiple Vaișnava voices can enrich and expand the Christian-Rāmānuja comparative discourse.

Some of the reasons for the Rāmānuja preference in Christian-Vaiṣnava comparative thought may be historical, tied up in the colonial study of Hinduism, or even earlier, in the sheer influence of Rāmānuja on other Vaisnnava systems. Since the colonial period, Śaṇkara's Advaita Vedānta has been a subject of special fascination for the Western study of Indian religions. As Sardella and Ghosh have described in their work on the Bhägavata Purāna's reception history, $19^{\text {th }}$ century Christian missionaries often considered the lìlā of Kṛṣna, and the Purānas' theistic narratives in general, to be inappropriately carnal and immoral. ${ }^{1}$ Influenced by Christian critiques, the British-educated Indian

Gopal Gupta is Associate Professor at the University of Evansville. His book, Illusion and Identity, Maya in the Bhāgavata Purāna, is forthcoming from Oxford University Press. Some of his recent publications include, "The World as Illusion: Environmental Implications of the Doctrine of Māyā" (Journal of Vaiṣnava Studies 2015) and “'May Calamities Befall Us at Every Step:' The Bhägavata's Response to the Problem of Evil" in The Bhāgavata Purāna, Sacred Text and Living Tradition (Columbia University Press 2013). Gupta is the editor for the Journal of Hindu Christian Studies. 
reformers of the bhadraloka, such as Rammohun Roy (1772-1833), Bankim Chandra (1838-1894) and Vivekananda (1863-1902), found the amorous play of Kṛṣna in the Bhāgavata to be a source of embarrassment. The indigenous bhadraloka came to regard the Bhāgavata's account of Kṛṣna and the gopiss as a celebration of moral misconduct, and thus both Christian missionaries and Indian intellectuals undermined the importance of the Bhāgavata and the Kṛ̦na-centered Vaișnava traditions, in favor of Advaita Vedānta which they portrayed as the central core of Hinduism. ${ }^{2}$

As scholarship broadened to recognize the importance of non-advaitic traditions within Hinduism, Rāmānuja's Viśisțāāvaita may have served as a natural bridge to Vaișnava thought. In comparison to the Bhägavata, Rāmānuja's Vaiṣnava Vedānta is theologically nearer to Śaṇkara's Vedānta, and Rāmānuja's Vaishnavism, centered on the Viṣnu Purāṇa and worship of the wedded Laksmi and Viṣnu, presents fewer problems than the Kṛṣnacentric traditions. Furthermore, Rāmānuja is the earliest Vaiṣnava to write a commentary on the Brahma-sutra and, as Martin Ganeri has observed, Vedāntacize, the Vaiṣnava tradition. ${ }^{3}$

The fact that Rāmānuja is the founder of the largest and most influential Vaiṣnava tradition may have also made him an attractive choice for Christian comparative study. Most traditions within Vaiṣnavism are deeply influenced by Rāmānuja, more than by any other Vaiṣnava theologian. Take, for example, the $16^{\text {th }}$ century Caitanya Vaisnava tradition which aligns itself formally with Madhva, although its major thinkers, such as Jivva Gosvami, draw more heavily from Rāmānuja than Madhva. ${ }^{4}$ This is partly due to the fact that Rāmānuja's philosophy of qualified non-dualism is more characteristic of the philosophy of Vedānta and Samkhya texts. Gerald Larson, in his work on Samkhya, notes that bhedäbheda is by far the most popular position in these texts ${ }^{5}$, and Sheridan argues the same for the Bhāgavata Purāna. ${ }^{6}$

Given that Rāmānuja's influence is immense in the Vaiṣnava tradition, the Christian engagement with Rāmānuja makes sense. However, Madhva and other Vaiṣnava thinkers offer innovative and distinctive contributions to Vaiṣnava theology, and taking them seriously would till new ground in comparative theology. To reflect upon the question of what is gained and lost by adding comparands, I would like to select a single theological issue-creation ex-nihilo as developed by Thomas Aquinas-and examine the differing results that emerge when we compare with three influential Vaishnava theologians: Rāmānuja, Madhva, and Jīva Gosvami.

In his study of Rāmānuja and Thomas Aquinas, Martin Ganeri has noted that "in earlier Thomist encounters with Rāmānuja's work there was felt to be a fundamental contrast between Aquinas's doctrine of divine simplicity and Rāmānuja's insistence that we can only know reality, including divine reality, as complex." In the course of his work, however, Ganeri has shown that such a contrast is exaggerated. Rāmānuja, like Aquinas, insists that "ultimate reality is entirely noncomposite in its existence." ${ }^{8}$ How successful Rāmānuja is in demonstrating that God is both complex and immutable is open to debate. For Rāmānuja, creation is real and distinct from God, yet fully present in God, the cause. Souls are also truly distinct, but they are inseparably related to, completely dependent on, and eternally present in their Cause (amsaamsin).

Madhva's views regarding the "oneness" of God offer an alternative to Rāmānuja's 
viśiștāâvaita. Madhva rejects key ideas in viśiștādvaita, such as Brahman's creative selftransformation (parināma-vāda) and oneness and difference (bheda-abheda), asserting that whatever is incompatible with the divine sovereignty should be rejected. Madhva's emphasis is on Brahman as the one independent Lord whose supreme will controls the immense variety of different entities throughout the universe, each with its distinct innate characteristics. Madhva diverges rather radically from the other Vaiṣnava theologians on the nature of creation, and on what constitutes the substantial cause of the universe. He does not accept that Brahman himself comprises the substantial cause (upadāna) of the world and the individual living beings. ${ }^{9}$

Similar to Madhva, Aquinas considers and rejects the idea that God is either the formal or material cause of the world on the basis that such an idea entails that God is in composition with other things. Aquinas argues that the material causes of things are in composition with them, and thus God cannot be the material cause of the world..$^{10}$ Madhva and Aquinas agree that God is not the material or substantial cause of the world.

Madhva further believes that prakrti, the world, is beginningless. Aquinas also allows for the possibility of an eternal world. He writes, "Those who would hold that the world was eternal, would say that the world was made by God from nothing; not that it was made after nothing, according to what we understand by the term creation, but that it was not made from anything." 11 When creation ex-nihilo is understood in this way, it indeed appears that Madhva and Aquinas are teaching virtually the same doctrine. A cursory study of Madhva and Aquinas suggests that, in comparison to Rāmānuja, Madhva's ontology is closer to Aquinas. But a deeper study reveals that the matter is far more complex.

Although Aquinas posits that God is not the material cause of the world, and he agrees that the world could be eternal, Aquinas believes that matter is created by God (exnihilo) and God is responsible for every aspect of its existence. "Aquinas sees the postulation of uncreated matter as resulting from a failure to account fully for the existence of things, in which only accidental or substantial change of form is felt necessary to explain, rather than the existence of things as such."12 For Aquinas, creation ex-nihilo entails that God creates matter and the world out of nothing.

Madhva, on the other hand, posits that although the world is utterly dependent upon God, it is not created by him. Madhva does not believe that God is the material cause of the world, nor does he believe that the world has a beginning. Thus, he contends that prakrti, nature, in its unmanifest form, is co-eternal with God, and therefore not created by God. As Deepak Sharma points out,

The Madhva god is like a 'chef' who uses eternally existent 'ingredients,' namely prakrti, to 'cook' the universe. The Madhva god is an instrumental, rather than material, cause... The idea that material entities evolved from prakrti has its roots in the Samkhya tradition, one of the oldest traditions of South Asian speculation. Though the mechanism of the evolution of prakrti differs, Madhvacarya shares the belief that previously unmanifested prakrti manifests itself and differentiates itself into worldly entities through the will of Viṣnu."13

Madhva ascribes to Samkhya metaphysics, which state that prakrti and purusa are coeternal. He then distinguishes his own Dvaita philosophy from Samkhya by claiming that prakrti is eternally and wholly dependent 
upon purusa. The idea of uncreated matter is a concept that Madhva embraces, but a notion that Aquinas fiercely opposes.

Rāmānuja adheres to the idea that God is the material and substantial cause of the world and all its living beings. The implication of this is that Rāmānuja sees the world as beginningless and he sees matter and the souls as created by God. He believes "that the soul is created by Brahman, is ruled by it, constitutes its body, is subordinate to it, abides in it, is preserved by it, is absorbed by it, [and] stands to it..."14 Thus, similar to Aquinas, Rāmānuja believes that the world is eternal and that matter and the souls are created by God. Both Rāmānuja and Aquinas do not accept Madhva's doctrine of uncreated matter.

Thus, Rāmānuja and Madhva are each theologically near to (and far from) Aquinas in different ways. Madhva believes matter is uncreated, while Aquinas does not. Rāmānuja believes that God is the material cause of the world, while Aquinas does not. Each Vaiṣnava theologian, however, develops his own theological thought and has unique contributions to offer in comparative theological work. When reading Rāmānuja and Aquinas together, we learn that they both believe that matter is created by God, but they do so in different ways. When reading Madhva and Aquinas together, we learn that they agree that God is not the material cause of the world, but for very different reasons.

A third Vaisnava ontological position regarding the relationship between God and the world is presented by the Chaitanya tradition, which draws from, and often attempts to synthesize, the teachings of Rāmānuja and Madhva. This theological position is called acintya-bhedābheda, inconceivable oneness and difference. In regards to the nature of the world and creation, this doctrine states that the world is inconceivably one with, and different from, God.

In this doctrine, the use of the word acintya, inconceivable, is significant. According to Chaitanya Vaiṣnava theology, the world is the energy, sakti, of God, Bhagavān. Both Bhagavān and his śaktis are fully real. Regarding the relationship between them, Bhagavān and his śaktis are identicaland they are different. The difficulty arises in recognizing these two facts simultaneously, and the inability to do so leads to acintya. And this inconceivability arises necessarily, for a contradiction is inaccessible to the intellect, in principle.

The concept of acintya does not need to be limited to Bhagavān and his śaktis. In the Bhāgavata Sandarbha, Jīva Goswami points out that the relationship between any object and its energy is inconceivable to the mind. He quotes from the Vișnu Purāna, "O best of ascetics, the śaktis of all beings are outside the range of reasoned knowledge. Therefore, Brahman's natural śaktis, such as creation, are also such-just like the heat of fire." ${ }^{15}$ Kapoor explains:

We cannot think of fire without the power of burning; similarly, we cannot think of the power of burning without fire. Both are identical. Fire is nothing except that which burns; the power of burning is nothing except fire in action. At the same time, fire and its power of burning are not absolutely the same. If they were absolutely the same, there would be no sense in... saying "fire burns."

The theory of acintya-bhedābheda could be useful in understanding Aquinas's doctrine of creation ex nihilo. In his writings, Aquinas attempts to embrace two positions: 1) God is the creator of matter in every aspect of its existence and 2) God is not the material cause of the world. It is plausible that the doctrine of 
acintya may be useful to a Thomist in simultaneously maintaining, and making sense of, these two positions. In the context of the object-energy relationship, God is the object, and matter is the energy. Although the energy, matter, is created by God in all its being, and is therefore nothing but God, it is inconceivably simultaneously one with, and completely different from, God.

Thus, Madhva and other Vaișnava thinkers offer innovative and distinctive contributions to Vaișnava theology, and taking them seriously reveals new pathways in Aquinas-Rāmānuja, and, more generally, Christian-Vaiṣnava comparative theology. We have seen that a single theological issuecreation ex-nihilo as developed by Thomas Aquinas-brings different results when we

\section{Notes}

${ }^{1}$ Ferdinando Sardella and Abhishek Ghosh, "Modern Reception and Text Migration of the Bhāgavata Purāṇa," in The Bhāgavata Purāna: Sacred Text and Living Tradition, eds. Ravi Gupta and Kenneth Valpey (New York: Columbia University Press, 2013), 227.

2 Sardella, "Modern Reception and Text Migration of the Bhāgavata Purāṇa," 225-231.

${ }^{3}$ Ganeri, Martin, Indian Thought and Western Theism: The Vedānta of Rāmānuja (New York: Routledge Taylor and Francis Group), 5. DOI: https://doi.org/10.4324/9781315731339

${ }^{4}$ Ravi Gupta, Chaitanya Vaisnava Vedanta of Jiva Goswami: When Knowledge Meets Devotion, (London: Routledge, 2007), 35. DOI: https://doi.org/10.4324/9780203500682

5 Gerald Larson, Classical Samkhya: An Interpretation of its History and Meaning, (New Delhi: Motilal Banarsidass, 2011).

${ }^{6}$ Daniel Sheridan, Advaitic Theism of the Bhagavata Purāna, (New Delhi: Motilal Banarsidass, 1986), 42. read it in light of three influential Vaishnava theologians: Rāmānuja, Madhva, and Jīva Gosvami. Reading Rāmānuja with Aquinas highlights and obscures certain elements of their theologies because of their respective similarities and differences, and an AquinasMadhva or Aquinas-Jīva Goswami comparison highlights and obscures other elements of their respective theologies. Furthermore, we have seen that reading Aquinas-Madhava and Aquinas-Jivva together not only highlights elements of their respective theologies, but also elements of Rāmānuja's theology. Thus, new insights will be gained in ChristianVaiṣnava and Christian-Rāmānuja comparative work as we engage with these missing Vaiṣnava voices.

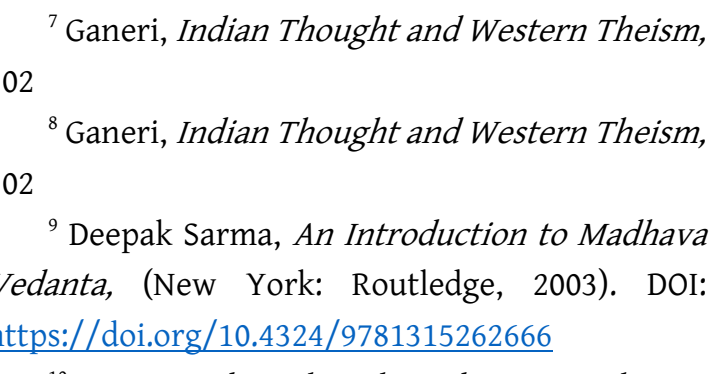

${ }^{10}$ Ganeri, Indian Thought and Western Theism, 134.

${ }^{11}$ Thomas Aquinas, Summa Theologica 1.46.2 ad 2, in Ganeri, Indian Thought and Western Theism, 143.

${ }^{12}$ Ganeri, Indian Thought and Western Theism, 135.

13 Sarma, An Introduction to Madhava Vedanta, 61

${ }^{14}$ Ramanuja, Sri Bhasya, 2.3.32.

15 Visnu Purāna in O. B. L. Kapoor, The Philosophy and Religion of Sri Caitanya, (Delhi: Munshiram Manoharlal Publishers, 1977).

${ }^{16}$ Kapoor, The Philosophy and Religion of Sri Caitanya, 153. 